DOI: 10.1515/ausfm-2017-0008

\title{
Post-Modern, Post-National, Post-Gender? Suggestions for a Consideration of Gender Identities in the Visual Artworks and Moving Images of Neue Slowenische Kunst
}

\author{
Natalie Gravenor \\ independent scholar \\ E-mail: natgravenor@gmail.com
}

\begin{abstract}
Active since 1980, the multidisciplinary Slovenian art collective Neue Slowenische Kunst (NSK, New Slovenian Art) and its branches, the fine arts group IRWIN, industrial music band Laibach and theatre troupe Gledališče Sester Scipion Nasice (The Scipion Nasice Sisters Theatre), have seen their works widely and often controversially discussed, most often in the context of subversion and over affirmation of totalitarian imagery, as well as the contemporary nation-state and nationalism. Gender, as another often essentialist category, has not figured prominently in the analysis of NSK's output and impact. This paper proposes some areas (participation, representation) for investigation, as well as points of departure for a theoretical framework starting with key texts on gender by Judith Butler and R. W. Connell to analyse the moving images, performing and fine art produced within NSK in terms of the role gender plays therein, as well as its relationship to the construction of other defining categories such as nation and class.
\end{abstract}

Keywords: gender, nation-state, music, video, fine arts.

\section{Introduction}

The art collective Neue Slowenische Kunst (New Slovenian Art) is an art collective founded in 1980s Yugoslavia. It encompasses multiple disciplines (visual arts, graphic design, theatre, music, film and philosophy/theory) and explores questions of identity, particularly through the prism of the nation-state and totalitarianism. By 1992, Neue Slowenische Kunst founded the NSK State as "State in Time," thus turning to a post-national discourse. The NSK State in Time project opened spaces for the reflection about and experimentation with 
new forms of social organization, including new myths, rituals and symbols. The prefix post harbours the hope of finding a solution to the damage caused by the implosion of the Yugoslav superstate, the ensuing ethnic conflicts and their violent generation of identity on the basis of nation, distinction and exclusion.

Besides nationality, sex or gender is the defining (officially defined) criterium of a person's identity. Sometimes hierarchical and immobile gender relations are essential components of national identity. So far, gender as an analytical category has been seldom discussed in relation with NSK. What role do gender issues play within the NSK? Has the post-national discourse rendered gender an irrelevant category? What is the evolution of how gender roles and identities are depicted in NSK over time? The following article should be understood as a first tentative approach, adding thought fragments to these and other questions on the topic of NSK and gender, encouraging additional questions that need to be formulated and investigated.

This initial discussion suggests the works of the following gender theorists as a theoretical framework. Firstly, with Masculinities, Australian sociologist R. W. Connell provides a comprehensive sociological study and history of ideas that not only delineates shifting concepts of masculinity (as a key concept of gender) as a function of particular social structures over time, but also articulates a scientific method that seeks to offset the deficiencies of socio-biological and social construction models of gender and sexuality. Furthermore, US philosopher Judith Butler's post-modernist approach and foregrounding of social construction and performance seems appropriate for discussing the NSK artistic project. These theoretical considerations, particularly those of Connell, inform the thick description and analysis used to discuss various visual and also musical articulations of NSK according to gender issues, after a short empirical overview of the participation of female (-identified) actors in the NSK and NSK State.

\section{The Participation of Women in New Slovenian Art and the NSK State}

Neue Slowenische Kunst was founded as an umbrella brand in the mid-80s in the Yugoslavian Socialist Republic of Slovenia by previously active artist groups like Laibach(kunst) and IRWIN. There was a myth of "Gender Equality" in socialist Yugoslavia - similar to the mythic equality purported in other "people's democracies" at the time (also in distinction against the inegalitarian, exploitative West). In fact, the percentage of employed women was higher than in many Western European countries, conditions for working mothers, such as access to childcare 
were better, but the double burden of career and housework was as pronounced in the East as it was in the West, and traditional gender roles had not disappeared. The art world, as a subset of society, was like in the "West" a "Boys' Club," with the exception of artists such as Marina Abramović, Marina Gržinić, Sanja Iveković. (In the international art world dominated by the "West," female artists from Eastern Europe were, as Bojana Pejić angrily stated, doubly marginalized - by gender and origin, see Kowalczyk-Łagodzka-Zierkiewicz 2010.) This is the social and historical context in which the aforementioned artists and later NSK were operating.

Many artists in Eastern Europe (once again, Sanja Iveković is an exception) avoided the F-word feminism because it was considered a "bourgeois" category. Nevertheless, the work of these artists negotiates core concerns of feminism: rebellion against oppression and reduction of the woman, the questioning of masculine hegemony and its effects, claiming self-determination of the female body, taking responsibility for more visibility, equality of opportunity and participation, dissolution or reconfiguration of the dichotomy private/ public, breaking the shackles of heteronormativity and necessity of reproduction (Pejić 2009, 23).

Interestingly, few artists involved in the cosmos of Neue Slowenische Kunst were female, except one of its most influential personalities. The dramaturg and art theorist Eda Čufer was an NSK co-founder and director of theatre companies such as Gledališče Sester Scipion Nasice (the activities of which will be discussed later). She was a driving force behind the foundation of both New Slovenian Art, the Gledališče Sester Scipion Nasice being one of its constituent parts, and the NSK State in Time. Together with members of IRWIN she wrote founding manifestos, and was instrumental in the planning of constituent actions such as the creation of virtual embassies in Moscow and Berlin. To date Čufer fulfils a role as intellectual leader (ideologue?) and facilitator of the NSK idea.

Since the founding of the NSK State in Time in 1992, 1200 women (of 6000 NSK Citizens) sought NSK "citizenship." This begs the question of what incentives or deterrents there are for women to apply for a NSK passport (and offers an interesting future topic for empirical research). The First Congress of NSK Citizens in Berlin in 2010 saw a strong male majority. Of 31 delegates, who were selected in an open application process for all NSK citizens to discuss the future of the NSK State and propose their own innovations, four were women. One female delegate did speak out for consideration of gender issues, for greater incorporation and participation of women and the exploration of "hidden history." ${ }^{1}$ This was included in the documentary film Time for a New State,

1 Documentary film Time for a New State: $1^{\text {st }}$ NSK Citizens Congress, Berlin by IRWIN in collaboration with 
First Congress of NSK Citizens State in Time (2013), Berlin by IRWIN and Igor Zupe (writer: Eda Čufer), an audio-visual record of the results and mood of the Congress. This raises the question whether there should be Women's Fora in NSK as platforms for articulating and discussing/ developing further demands, how to operationalize measures like a female membership quota, special events for female delegates, etc. Or does it even make sense to encourage this type of networking and discourse, because it may simply reflect the dynamics of the official democracies in miniature, which NSK delegate Christian Matzke warned against in another context. Another suggestion was the creation of "propaganda" targeted to attract more women to join NSK (see McGrady 2011).

Another possible reason for the (far) less pronounced reflection of gender issues in the NSK discourse can be found in the founding principles: overcoming individuality and creating a collective organism. In the founding manifesto of Laibach, "10 Items of the Covenant," Article 4 states: "The triumph of anonymity and facelessness has been intensified to the absolute through a technological process. All individual differences of the authors are annulled, every trace of individuality erased." Among the Five Principles of Friendship, which are listed in the NSK passport, male forms are exclusively used, like "brotherly." 3 To this day, in many languages the masculine form is assumed to also include females; only in women-only groups is this also grammatically signified (e.g. the French female third person plural "elles").

For the creation and perfection of a collective identity as espoused by the NSK State, the question arises to what extent gender may or may not even be a relevant category. The category gender serves to assign a person to a larger group based upon the prevailing binary gender model. Knowledge from the past 25 years, especially the work of Judith Butler on gender performativity, has created a potential for living and expressing changing, multiple, contradictory, fluid and individual gender identities. Seen in the context of the 1980s, when there was significant backlash against the achievements of various feminist movements (as against other progressive, egalitarian activism) and the AIDS crisis led to sexuality and gender being negotiated in essentialist terms with repressive effects, Butler poses a vital question in her seminal book Gender Trouble: "what best way to trouble the gender categories that support gender hierarchy

Igor Zupe (2013).

2 Laibach: The 10 Items of the Covenant. 1982. http://garagemca.org/en/materials/1246?id=14. Last accessed 07. 09. 2017.

3 See: http://nsk.mg-lj.si/wp-content/uploads/2015/05/MG-MSUM_nsk_VODIC_eng_ogled7_pred-tiskom-1. pdf. Last accessed 07. 09. 2017. 
and compulsory heterosexuality?" (1990, viii.) Taking the practice of drag (in particular that of performer Divine in the film Female Trouble and other works by director John Waters) as a point of departure and foregrounding the gap between acts "expressive" of "natural" versus "performative gender practices" (1990, viii) $^{4}$ (particularly in, but not restricted to queer culture), Butler furthermore writes: "Gender is in no way a stable identity or locus of agency from which various acts proceed; rather, it is an identity tenuously constructed in time - an identity instituted through a stylized repetition of acts [...] through the stylization of the body [...] the mundane way in which bodily gestures, movements and enactments of various kinds constitute the illusion of abiding to gendered self" (1988, 519, emphasis in original). Butler thus focuses on both the fact and act of social construction, posing basic phenomenological questions about the subject's agency, if the subject is constituted through social practice (1990, 142-143).

In terms of analytical relevance for the NSK project, Butler furthered the discussion of malleable, multiple, non-traditional gender identities, which figure in the NSK works to a certain degree. Furthermore, gender studies use analogous concepts of identity construction and performance to the NSK project, likely due to the fact that both arose during the 1980s and 1990s under the influence of structuralism and post modernism and its core notions of deconstruction and bricolage.

\section{Representation: Gender Images and Designs in Various Branches of NSK}

Certainly, just as or even more significant for gender relations than the (quantitative) analysis of female participation in NSK is an analysis of the explicit or implicit (absence as a sign) representations of gender roles and images. This includes the representation of different forms of sexuality. Gender imagery and roles in the cultural production of the respective branches of NSK are examined below.

\section{Laibach}

\section{a) Masculine}

Gender research is often equated with and reduced to a feminist approach and a focus on women and the feminine. However, the analysis of images of

4 And also Butler (1988). This article is seemingly an earlier articulation of arguments presented in the section "Bodily Inscriptions, Performative Subversions" of Gender Trouble (1990). 
masculinity is just important to delineate the boundaries and continuities for the development of a multi-layered understanding. The music group Laibach with its militarist-totalitarian image offers, beyond its well-explored project of ideology, deconstruction approaches to thinking about constructions of masculinities. The Australian gender researcher R. W. Connell sees the state as "masculine institution" and recognized in the military and the industrial capitalist mode of production the two essential constituents and negotiating pillars of hegemonic masculinity of the 20th century (Connell 2005, 73). Connell uses the concept of hegemonic masculinity as one category alongside "protest masculinity" and masculinity "reformed" in reaction to criticism from women's movements to foreground the importance of power relations $(2005,120)$. "Masculinity, as the argument so far has shown, is not a system in that sense. It is, rather, a configuration of practice within a system of gender relations." (Connell 2005, 84.)

Connell charts transformation over the past 200 years as gentry (hereditary land owners) masculinity as the hegemonic mode faced these three developments: "challenges to the gender order by women, the logic of the gendered accumulation process in industrial capitalism and the power relations of empire" $(2005,191)$. The increased importance of bureaucratic process and exchange value in capitalist society had not led to the de-valuing of military might and violence. Instead, "violence was now combined with rationality, with bureaucratic techniques and constant technological advance in weaponry and transport" (Connell 2005, 192).

As a particularly "exemplary form of hegemonic masculinity" ${ }^{5}$ Connell has cited fascism, which took the militarization of society to terrible extremes. "In gender terms fascism was a naked reassertion of male supremacy in societies that had been moving towards equality for women. To accomplish this, fascism promoted new images of hegemonic masculinity, glorifying irrationality (the 'triumph of the will,' thinking with 'the blood') and the unrestrained violence of the frontline soldier. [...] The defeat of fascism in the Second World War cut off this turn in hegemonic masculinity. But it certainly did not end the bureaucratic institutionalization of violence. [...] The Red Army and United States armed forces which triumphed in 1945 continued to multiply their destructive capability, as the nuclear arsenal built up." (Connell 2005, 193.) In the context of the late Cold War and the menace of institutionalized violence precipitating world destruction which Connell is referring to, fascism (and totalitarianism in general) has been the core object of Laibach's complex aesthetic deconstruction of the traumata of the $20^{\text {th }}$ century. They are exposed through the band's use (simulation) of hyper- 
military imagery, sonics and rituals and organization through the devices of overaffirmation and irony.

About the sexes in industrial societies Connell writes: "The expansion of industrial production saw the emergence of forms of masculinity organized around wage-earning capacity, mechanical skills, domestic patriarchy and combative solidarity among wage earners. Women were, in fact, a large part of the original workforce in the textile factories of the industrial revolution, and were also present in coal mining, printing and steelmaking. They were involved in industrial militancy, sometimes were leaders of strikes, as Mary Blewett has shown for the weavers of Fall River, Massachusetts. The expulsion of women from heavy industry was thus a key process in the formation of working-class masculinity, connected with the strategy of the family wage and drawing on the bourgeois ideology of separate spheres" $(2005,196)$. Connell furthermore describes labour with at least some parallels to the military: "Heavy manual work calls for strength, endurance, a degree of insensitivity and toughness, and group solidarity. Emphasizing the masculinity of industrial labour has been both a means of survival, in exploitative class relations, and a means of asserting superiority over women" $(2005,55)$. The "martial" and the "industrial" are essential topoi of Laibach. Though likely not intended as a critique of hegemonic masculinity, the use of these topoi opens a space to apply gender studies to analyse power relations in general [Fig. 1].

On first view, Laibach appears consistent with the observation of the late Polish art critic and curator Piotr Piotrowski that in socialist societies, men are attributed active and women passive roles (2012, 246-247). Laibach's appearance is consequently "tough:" short hair (singer Milan Fras sports a manly moustache, and the upper lip of Dejan Knez was also adorned with fuzz for a time), paramilitary or pseudo-military uniforms or naked chests, motionless faces, stiff movements. In early stage shows Laibach used fire, an essentialist, "male" coded element (water, on the other hand, has "feminine" characteristics attributed to it). The Laibach sound is loud and brutal; an electronic sound storm which also suggests military equipment: drums, Alpine Horn, orchestral bombast. The recurring motif of the deer is a symbol for the Slovenian nation and male potency, especially as used within R-rated jokes or references. The deer is also a postmodern gesture it is a reference to the $19^{\text {th }}$ century Scottish landscape painter Edward Landseer. Laibach uses natural symbolism (which also includes Alpine landscapes, especially Slovenia's highest peak, Mount Triglav, appearing in music videos of the group such as the 1986 clip Opus Dei (Life is Life) (directed by Daniel Landin, 
1986) or the archaic family tableau in Sympathy for the Devil (directed by Peter Vezjak, 1988) and insignia of the industrial age in equal measure. Visual motifs include gears, hammers, factories and male workers (often stripped to the waist). Rhythms reminiscent of the assembly line often dominate in the music. The very first recording of Laibach, Industrial Ambients (1980) was actually a "field recording" of factory noises from the band's hometown Trbovlje.

Laibach, it could be argued, pursues an implicit, systemic gender discourse with its use of military and industrial signifiers and almost parody-like masculinity (bringing to mind again Butler's theory of gender performativity).

\section{b) Feminine}

Just like in the spheres of society and the military industrial work (until the end of the 20th century) for which the band is both subset and a distorting mirror, women played no major role in the early years of Laibach. This changed in 1987, when Anja Rupel, singer of popular Slovenian synthpop group Videosex, joined Laibach as guest vocalist on the Beatles cover version Across the Universe. Rupel was also a lesbian icon who sang the first Slovenian female-addressed love song, Ana from the year $1984 .^{6}$

Prior to this, the 1986 Life Is Life video features a cameo appearance by a bare-bosomed female archer wearing the same trademark headdress as singer Milan Fras. Furthermore, Laibach began featuring female percussionists in live performances. The drum in rock music has long been a "masculine" instrument, so while the presence of female percussionists is noteworthy, they are still relegated to the background, supporting the male band members. A more significant indication of a stronger female presence is featured singer Mina Špiler, formerly of the indie band Melodrom. In 2006, she joined the "Volk" tour as a guest singer; now she is cited as an official band member, with the deep gravelly voice of Milan Fras, lead singer since the death of the first Laibach singer Tomaž Hostnik in 1982 and one of the band's trademarks, receding more and more into the background. Does the sweeter aural and visual appearance of Špiler have commercial motives, an overture to a female fan base? On the Laibach album Spectre (2014) and the accompanying tour, Fras and Špiler share lead vocals, often singing alternately within a song. Harmonies, however, are rare (except

6 See Bulc, Gregor. Hard Bosom: Top Pro-Gay Tracks from ex-Yugoslavia (Part One), article on Bturn-Blog, http://bturn.com/8384/hard-bosom-toppro-gay-tracks-from-ex-yugoslavia-part-one. Last accessed 11. 04. 2017. The first Yugoslav pop song with openly lesbian lyrics was most likely Moja prijaleljica (My girlfriend) by Croatian group Xenia from 1982. 
for the Warme Lederhaut [2013], the cover version of The Normal's JG Ballard homage Warm Leatherette) - duelling duet and separatism rather than genderblending? This "separatism" sees Fras and Špiler showcased in separate tracks on the otherwise largely instrumental Also sprach Zarathustra (Thus Spoke Zarathustra, 2017), music composed for a theatre piece based upon Friedrich Nietzsche's philosophical work. The album harks back to the band's earlier, more martial (sometimes orchestral) sound, after the pop-oriented "Spectre."

Another recent work featuring Laibach is the documentary Liberation Day (2016), chronicling the band's journey to Pyongyang in 2015 as the first Western rock group to ever perform in North Korea. The film focuses on the preparations for two big shows (of which one was cancelled by the North Korean authorities) as the band members and director Traavik (who set up the concert and acts as go-between between Laibach and the North Korean handlers) deal with technical problems and censorship issues. The different band members' reactions to these challenges are stereotypically "gendered." While the males are generally stoic or solution-oriented (if exasperated at times), Špiler is shown in a barely suppressed outburst, when she is informed that a song for which she especially learned the Korean lyrics and was to perform in a traditional Korean-style dress was removed from the program at the last minute. It's however unclear if these reactions are typical of the band members' actual temperaments or shaped by subconscious gender stereotypes. An interesting side note is that on the film's website, Fras is referred to as "the figurehead" and Špiler as "the first lady" (with founding member and purported "mastermind" Ivan Novak described as "the supervisor"). ${ }^{7}$ North Korean women appear in the film largely as performers in the choir or professionals working at the concert venue in a slightly gendered division of labour (male technicians, female interpreter) that are visible but not interacted with (the North Koreans the audience gets to know better are the male officials responsible for supervising the concert). Gender equality in North Korea is constitutionally guaranteed, and women frequently shoulder the double burden of fulltime employment ( $48 \%$ of the workforce in $2016^{8}$ ) and responsibility for housework and childcare. ${ }^{9}$ Since 2015 women are also required to serve in the

7 See official Liberation Day website, http://www.liberationday.film/players/. Last accessed 31. 07. 2017.

8 See http://data.worldbank.org/indicator/SL.TLF.TOTL.FE.ZS?locations=KP. Last accessed 31. 07. 2017.

9 Ju-min Park, In North Korea, men call the shots, women make the money, Reuters.com, May 15, 2015. Last accessed 31. 07. 2017. 
military. ${ }^{10}$ At the same time, North Korean society is still shaped by patriarchal attitudes. ${ }^{11}$ Liberation Day supports the notion of women's subordination in North Korea (while not really contradicting the de jure equality) although the Laibach entourage, too, is a boys' club (except for the largely objectified Špiler). Is this an indication of the actual gender power relations within Laibach or just for the tour, to acquiesce to North Korean expectations, real or imagined?

In Sašo Podgoršek's documentary Divided States of America (2004) about Laibach's US tour immediately after George W. Bush's re-election, Laibach's following is a display of diversity: in addition to the usual (male) suspects from the Goth-Wave-industrial scene and also "White supremacists," the viewer also meets leftist African American Beatniks and a variety of women whose only common trait is their fascination with Laibach. This ranges from an amorous/ sexually coloured admiration of Milan Fras to various appreciations of Laibach's social potential.

Laibach's lyrics, too, have become more feminized. While lyrics in the early years like samples of Tito speeches, texts about surveillance and war were in the foreground or the songs were instrumentals. One instrumental is Slovenska žena (released in 1985), meaning "Slovenian woman." The usual noise from metal-electronic sounds in assembly line rhythms is overdubbed with high, echoing female vocals which fade towards the end of the piece to return briefly. If Laibach sings about feelings and the elementary form of interaction between (not only) man and woman in Die Liebe (Love, 1984) it sounds like this: "Love is the great force that creates everything,"12 i. e. desexualized, abstract, totalitarian. In 2012 Die Liebe is sung live by Fras and Špiler, each singing verse and chorus successively, without harmony.

Laibach détournage cover versions of Eurotrash stompers ${ }^{13}$ like Life Is Life (1986), In the Army Now and Final Countdown (both 1994) and Mama Leone (2004) revealed not only a totalitarian "Hidden Reverse" in Western pop music - particularly evident in Geburt einer Nation (Birth of a Nation, 1987), in

10 See https://en.wikipedia.org/wiki/Women_in_North_Korea. Last accessed 31. 07. 2017.

11 Ask a North Korean: are women treated equally in your society? The Guardian, February 14, 2015.

12 Thanks to Alexander Nym for pointing out the double meaning in the original German lyric "Die Liebe ist die größte Kraft, die Liebe, die alles schafft." "Schafft" can be translated as both "create" and "accomplish."

13 Laibach has also covered songs from the "serious," partly male coded rock canon, such as the Beatles' entire Let It Be album (minus its title track, in 1988), Sympathy for the Devil by the Rolling Stones (1988), Ballad of a Thin Man by Bob Dylan (2012) and recently Love on the Beat by Serge Gainsbourg (2014). Ironically, Love on the Beat was the title track of Gainsbourg's 1984 album, with a cover featuring the Gallic macho wearing heavy female makeup. 
which Queen's One Vision became through a literal translation of the text with minimal changes an anthem of "Gleichschaltung" (coerced conformism). The cover version, especially of "female" coded Eurodance tunes, also softened and feminized the Laibach sound while strengthening the subversive potential (at least before the cover song strategy temporarily lost its bite due to repetition and less than imaginative execution).

\section{c) Queer}

The "male-dominated society" ("Männerbund") as also evident in the early stages of Laibach is often attributed with homoerotic undertones. And particularly fascist aesthetics have always exercised a strong fascination within gay subcultures the masquerade-like hyper-masculinity and the danger factor, frightening and pleasurable at the same time. British choreographer Michael Clark, an important player in the queer subculture in London in the 1980s, collaborated on his dance piece No Fire Escape in Hell (1986) with Laibach, an excerpt of which can be seen in Daniel Landin's music clip of Država (The State, 1985) [Fig. 2]. Clark said in Goran Gajić's documentary Laibach: Pobeda pod suncem (Laibach: Victory Under the Sun, 1988): "The music is strong, powerful and frightening and also has humour. Although Laibach would deny this." Another curio is a photo of band founding member Dejan Knež, on which he purses his lips to kiss another man. ${ }^{14}$ With the cover versions of Eurotrash and disco songs (see above), Laibach introduced the element of camp - ironic appreciation and deconstruction of kitsch - that is adopted from gay culture.

Other industrial groups and Laibach contemporaries such as DAF, Throbbing Gristle, Coil, Revolting Cocks and Laibach's Slovenian compatriots Borghesia, pioneers of the LGBT scene in Ljubljana, made their examinations of gender more explicitly than Laibach did, especially in terms of exploring transgressive, non-heteronormative sexualities. Queering as an interpretive method is not uncontroversial, particularly when it used to analyse cultural developments prior to the establishment of present-day categories, but queering Laibach seems appropriate, given the group's contemporaneity with the dawn of post-modern identity politics and exploration of fascist aesthetics as an articulation of an extreme, violent masculinity that subordinates and even excludes femininity. 


\section{d) Post-Gender $\rightarrow$ Post-Human?}

After the social and political upheavals of 1989-1991, which Laibach helped to engender (no pun intended), the band returned after a break with the album Capital (1993). ${ }^{15}$ It consisted entirely of original compositions and was a report on the new world order and accurate comment on the transformation from a planned to a market economy. In particular the music video for Wirtschaft ist tot (Economy is Dead, 1993, dirs.: Peter Vezjak, Laibach) staged the four members of Laibach as androgynous, even post-human, robot-like creatures: still recognizable in their typical costumes, but sprayed from head to toe with silver paint [Fig. 3]. Female figures appear too in the video, with recognizable feminine shapes and also covered in silver. The traditional roles are reversed: the women are raking in coal (literally, not figuratively), while the men perform office work such as answering the phone. Furthermore, the male vocals of Fras and the rest of the group are higher, sweeter, less guttural. Is this the result of (late) capitalism's feminization and commercialization?

The video of Final Countdown (dir: Sašo Podgoršek, 1994) takes the dehumanization a degree further [Fig. 4]. The clip both advertises the single of the same name and is a PSA to join the NSK State. Milan Fras (the other members are no longer recognizable as individuals) can be seen as 3D computer animation. He is founding an NSK Embassy on Mars, the building inspired by Jože Plečnik's phallic, never built design for the Slovenian Parliament building. Laibach and the NSK State have thus left the limitations of the (gendered) human body and the Earth behind.

Since the late 2000s a process of separation between Laibach, perceived as the dominant branch of NSK and the other branches ensued. It might be interesting to compare the increasingly diverging developments in relation to gender. Laibach's dominance is also why the group's activities are accorded the most space in this paper. The following comments and observations about gender representations in other NSK branches are first suggestions for closer examination.

15 Alexander Nym adds that the different formats of the album each offered variations on CD, LP and music cassette. The two latter formats contain different versions of the track Steel Trust by Laibach side project Germania, which represents Laibach's "female side" (according to a remark by Laibach spokesperson Ivo Saliger to Nym) and features both overtly romantic lyrics and their impressive delivery by a female voice. The result, especially in the vinyl version, in its relentless kitchiness, is something of a challenge to Laibach fans more attuned to their harsh and brutalizing sound. 


\section{Laibachkunst/ IRWIN}

Laibachkunst and later IRWIN largely created the visual elements for Laibach and also Gledališče Sester Scipion Nasice. Nevertheless, for the purposes of this paper, they are being examined as independent artistic phenomena. As for an initial investigation into gender aspects, four short works that provide starting points for an in-depth analysis will be discussed below.

Laibachkunst and IRWIN often portrayed women as "women" - not so much full-fledged figures as post-modern references. Images of femininity are often quotes from previous art works, the result of Irwin's/ NSK's artistic strategy of retrogarde as well as the postmodern gesture of quotation and collage. A particularly striking example is the poster for an exhibition by Laibach at the Art Gallery ŠKUC in Ljubljana in 1983. In the black-and-white silkscreen print an elderly lady drinking coffee smiles dreamily at the viewer. The cup is adorned by the black cross of Laibach "borrowed" from Malevich and Beuys. The image is an appropriation of the famous painting Kofetarica (Coffee drinker, 1888) by Ivana Kobilca. The Impressionist painter was the most famous visual artist in Slovenia at the time. Her visibility and success as a woman in the art world in the late 19th century was exceptional. Laibach's colour reduction (which eliminates the petit-bourgeois floral pattern and upholstery in the original for a stylized, almost Warhol-esque effect) and insertion of its own logos and copying by silkscreen added a layer of ironic feminist statement to this already iconographic image.

Irwin's assemblage cycle Malevich Between the Two Wars (1984-2000) is a carved wood framed like a Russian Orthodox icon, a collage of a picture of a Nazi sculpture with two naked warriors clinging to the same sword and in the background, a realistic portrait of a woman in warm, in some exhibition situations even golden hues. Her head is obscured by the naked warriors and the picture by Malevich, of a cross with a red and a black bar (the Suprematist primary colours) on a white background. Irwin's interest was probably less the role of the woman in the portrait (which serves only as a quotation of the accepted academic painting) and more the interplay between Nazi Art, Russian Orthodox devotional objects and Suprematism. In contrast to Laibachkunst's Kofetarica Poster, the use of a female portrait is not necessarily essential for the piece to work. Nonetheless, these assemblages generate a gender discursive momentum. They act almost like a visual equivalent to the Laibach track Slovenska žena (Slovenian Woman) - the male-militarist elements are dominant, but the female presence is both marginalized and constant, eternal. 
The next two works discussed are less quotations from art history, but rather social interventions in the microcosm of the art world. In NSK Panorama (1997), also by IRWIN, the commentary on gender discourse is striking. A colour photo shows people on a meadow that have formed a circle and are holding hands. Motion blur suggests the movement of a folk dance in progress. Women and men alternate in the circle. While the men (including IRWIN members) all wear dark or black suits, the women almost exclusively are dressed in Slovene national costumes, except for the half-hidden NSK co-founder Eda Čufer. All cheerfully take part in the dancing party. A simple and ironic statement about the interplay spread of the binary pairs tradition/ modernity and female/ male.

The last work, Namepickers (1998) by IRWIN, shows how the dichotomy East/ West can cancel out the male-female opposition. We see two identical photographs with Yugoslav/ Serbian artist Marina Abramović, who has been active in the West since the late 1970s and five members of IRWIN. Abramović is in black lingerie (with the Laibach-/ Malevich Cross bandaged on her right arm) lying on a bed and cared for by IRWIN. The left photo is signed by Marina Abramović and costs DM (German marks) 16,400. The right image is copyrighted by Bojan Brecelj and costs DM 1,200. Brecelj is an esteemed photographer in Slovenia, but not an international art star like Abramović, who lives in New York and is exhibited in all major museums. Namepickers acts like a reversal of the work of agitprop collective Guerrilla Girls, an identification of sexism and inequality in the art world. This is seen by the Guerrilla Girls, given the emancipatory claim of many artists and curators, as particularly hypocritical. Namepickers can be read as a plea against marginalized groups being played off against each other in the hope that various experiences of inequality be addressed with solidarity.

\section{Gledališče Sester Scipion Nasice (Scipion Nasice Sisters Theatre)/ Rdeci pilot (The Red Pilot)/ Kosmokinetisches Kabinett Noordung (Noordnung Cosmo-kinetic Cabinet)}

As mentioned in Section 2 (Participation), in 1983 Eda Čufer founded the theatre collective Gledališče Sester Scipion Nasice (Scipion Nasice Sisters Theatre) with Dragan Živandinov and Miran Mohar (from IRWIN), named after the Roman consul who exerted censorship on theatre performances. The collective had already determined the date of dissolution (1987) and thus anticipated the NSK State in Time, by being not a theatre within a fixed space, but rather a fluid platform for networking and cooperation. 
The collective planned their work in one-year periods. For the retrogardephase in 1986, the biggest action of Scipion Nasice, the performance of a "mashup" of France Prešeren's Slovene national epic Krst pri Savici (Baptism at Savica) with legends about the Triglav mountain was planned. The new piece was called Krst pod Triglavom (Baptism under the Triglav). Laibach, at the time still banned from public performance under their own name ${ }^{16}$ composed and performed the musical score. The set was designed by IRWIN, influenced by Russian Suprematism; a replica of Tatlin's Tower to the Third International was a central part of the decor.

Against the background of the Germanization and Christianization of Slovenia, a love story unfolds between the pagan Slavic war hero Črtomir and Bogomilla, a pagan priestess who had converted to Christianity. In the relationship Bogomilla sets the tone and she convinces Črtomir to be baptized for her sake. In the end the lovers go separate ways - Bogomilla "marries" Jesus (cf. Monroe 2005, 90) while Črtomir less voluntarily wanders the countryside as an itinerant preacher. In terms of gender aspects, Krst pri Triglavom is interesting in that the traditional male-female disparity is neutralized by other coordinates, in this case Christianity, which was becoming more and more powerful around the year 800 and could bring social advancement through conversion [Fig. 5]. Bogomilla appears to be the stronger of the two lovers, and her position was solidified with her Christianization. Črtomir, on the other hand, once the celebrated warrior, loses everything. In the video recording of the play by video artist Miha Vipotnik, panels are regularly displayed in the constructivist style with the inscriptions like "Female Emotions" and "Male Emotions." The displays indicate the gendercoded emotional difference, but are design rather than discursive elements.

While Gledališče Sester Scipion Nasice disbanded in 1987, the theatre group Rdeči Pilot (Red Pilot) emerged with many of the same key figures, then came Kosmokinetisches Cabinet Noordung, which successively continued the work until the mid-1990s. The founding manifesto of Rdeči Pilot states:

"WE, the members of 'Red Pilot' have no stage. WE are the KOSMOKINETISCHES THEATER 'RED PILOT.'

WE have no lungs, no liver and no balance organs, because WE are liberated from gravity.

WE have no genitals, as we have emancipated us from the freedom drive.

16 Thanks to Alexander Nym for the following supplementary information. The administration of Čankarev dom, arguably Ljubljana's most important cultural venue, decided to ignore the ban on Laibach's name by crediting them in public announcements, which was an important step both in terms of validating Laibach's position in the art world, as well as demonstrating the uselessness of the ban. 
WE build the observatory for the conquest of parallel worlds.

WE are workers that build the drama of the cosmos." ${ }^{17}$

Rdeči Pilot joins the conversation about the tendency for separation of identity (especially gender identity) from the body, seed and soil in the mid-1990s, in which Laibach and the NSK State also participated.

\section{Plurality and Opening: Folk Art}

Since the mid-1980s, followers of Laibach and NSK have produced images, texts, videos, websites and objects influenced by visual motifs of NSK as vehicles for their own creative and artistic reflection and as continuation of the art and ideas of NSK - this body of work is called Volkskunst or Folk Art (Monroe 2012, 15). Newly established NSK Embassies and NSK events in Leipzig, Berlin, Paris, London, Moscow, New York are becoming exhibition spaces and discussion platforms for Volkskunst. Until now, many of the artworks remained fairly close to the NSK symbolic world: Laibach Crosses, deer, uniforms and traditional costumes. Ever since the first NSK Citizens' Congress in Berlin in 2010, Volkskunst has become more diverse. This development was supported by a poster contest in the run up to the Congress and a call for Volkskunst works for an exhibition. Furthermore, one Congress objective was to find ways to promote diverse NSK culture (s?) by the citizens themselves. An analysis of Volkskunst according to gender criteria could be very productive with these initial questions: which kinds of images are produced (content analysis of images), who produces them, how are they disseminated and what options are available specifically for male and female citizen artists to participate in this image production? At this point, two examples will be described briefly as a stimulus for further analysis of Volkskunst according to gender and also other theoretical criteria.

Peter Blase's assemblage sculpture NSK Sledge (2011) consists of a replica of a human torso mounted on a sled. At the top of the sled is a picture of IRWIN against a black Malevich square of black slate. According to Blase, the torso is representative of all NSK citizens of all ages and genders. ${ }^{18}$ Particularly remarkable about "NSK Sledge" is the matter of fact symbolic integration of women like Jessica Beuys, shown with her husband and Beuys's photographer, Ute Klophaus.

17 Kosmokinetisches Theater 'Roter Pilot.' Founding manifesto (1987). In Gledališki Festival, Programme Brochure, Čankarev dom, Ljubljana. 1989. Reprinted in: Arns, Inke. 2002. NSK. Eine Analyse ihrer künstlerischen Strategien im Kontext der 1980er Jahre in Jugoslawien. Regensburg: Museum Ostdeutsche Galerie, 124.

Calvert 22, ed. 2012. NSK Folk Art. Catalogue, 33. London. 
This way Blase makes the people (women) visible who have supported the great artist Beuys in his work, but would otherwise have remained unknown. "NSK Sledge" is a tribute to the collective creative work, especially to those who do this work in secret, often the women.

Valnoir Mortasonge won the poster competition of the NSK Congress with a motif that brings together NSK delegates in a meeting room full of NSK insignia. The delegates all have human bodies, but the heads are animals such as deer, rooster, eagle and bear. Is Mortasonge's selection of exclusively male animal heads a reference to the male dominance among NSK delegates and a self-ironic reminder to delegates to maintain certain standards of debate culture and not to exhibit the negative behaviour traits associated with certain animals like the rooster?

\section{Summary}

This initial examination of selected visual and performing art, moving images and music produced by the branches of NSK provides first answers to the questions posed at the outset. In terms of the role gender issues play within the NSK, the discourse surrounding the state (in its extreme totalitarian incarnation), the military and industrial labour offers at least an implicit critique of hegemonic masculinity as defined by Connell that be further explored to investigate gender relations as a significant issue within broader questions of power relations in (late) capitalism as it has become the dominant economic system. Regarding the second question, particularly the music clips of Laibach in the mid-1990s and the manifesto of theatre group Red Pilot indicate that NSK indeed strove to overcome the category of gender along with that of nationality (interestingly, other categories such as class don't figure in this discourse) and promote a collective identity that transcends the human body as a whole. Thirdly, the depiction of gender roles and identities in NSK over time appears to have evolved from the hyper-masculinity that excludes women altogether or the treatment of women as abstract references in the early 1980s to more fluid identities and explicit critique of gender power relations in the 1990s, as exemplified with the visual art produced by IRWIN and music clips by Laibach such as Wirtschaft ist tot, which breaks down gender role assignments in the wake of the dissolution of socialism and crisis of late capitalism. In the mid-2000s, the strong vocal and visual presence of Mina Špiler has become a permanent addition to the previously all-male line-up; at the same time, traditional gender roles seemed to have returned and the masculine and 
feminine elements of Laibach as embodied by Milan Fras and Špiler are often segregated - an (ironic?) throwback to earlier societies where men and women lived separate but unequal lives? This change over time also indicates that the Laibach, as a branch of NSK, is even less explicitly dealing with gender issues, while still grappling with the nation-state. On the other hand, the inclusion of female participation as a topic at The First Congress of NSK Citizens in 2010 shows that the NSK State in Time now acknowledges gender as a relevant category within all the post-everything discourse. And the absence of explicit gender discourse is also a statement about gender power relations.

An investigation of the NSK State and its constituent groups of artists according to different gender aspects is at the beginning. The preceding remarks should serve as an inspiration to use gender discourse and its tools as an extension of analytical repertoire. Issues of public visibility and social participation of women, constructions of masculinity, queering, post-human discourse, culturalhistorical examinations of images of femininity and masculinity and more may provide new insights into NSK. The NSK State in Time is, by definition, always in motion, and therefore the instruments must be continuously developed and refined to map this "territory." The greater involvement of methods and concepts of the many approaches that are lumped together as gender studies - also in relation to other identity parameters such as nationality and class - could make a contribution to deep analysis and understanding the iconography, aims and impact of NSK.

\section{References}

Arns, Inke. 2002. NSK. An analysis of their artistic strategies in the context of the 1980s in Yugoslavia. Regensburg: Museum of East German Gallery.

Bulc, Gregor. 2012. Bosom Hard Top Pro Gay Tracks from ex-Yugoslavia (Part One). http://bturn.com/8384/hard-bosom-top-pro-gay-tracks-from-ex-yugosla via-part-one. Last accessed 15. 08. 2017.

Butler, Judith. 1988. Performative Acts and Gender Constitution: An Essay in Phenomenology and Feminist Theory. Theatre Journal vol. 40, no. 4 (December): 519-531.

Butler, Judith. 1990. Gender Trouble. New York/London: Routledge.

Calvert 22, ed. 2012. NSK Folk Art Catalogue. London.

Connell, R. W. 2005 [1995]. Masculinities. Los Angeles/ Berkeley: University of California Press. 
Kowalczyk, Izabela; Dorota Łagodzka and Edyta Zierkiewicz. 2010. Anger of Bojana Pejic. An interview by the occasion of the Gender Check exhibition at the Warsaw's Zacheta Gallery. August 24. http://www.obieg.pl/artmix/18402. Last accessed 10. 12. 2014.

Laibach. 1982. The 10 items of the Covenant. http://garagemca.org/en/ materials/1246?id=14. Last accessed 07. 09. 2017.

McGrady, Conor. 2011. The State as Utopian Work of Art. A Summary of the First NSK Citizens' Congress in Berlin. Brooklyn Rail June 3. http://www. brooklynrail.org/2011/06/express/the-state-as-utopian-gesamtkunstwerk-asummary-of-the-first-nsk-citizens-congress-in-berlin. Last accessed 15. 08. 2017.

Monroe, Alexei. 2005. Interrogation Machine. Cambridge, MA/ London: The MIT Press.

Monroe, Alexei. 2011. State of Emergence. A Documentary of the First NSK Citizens' Congress. London/ Leipzig: Plöttner.

Monroe, Alexei. 2012. NSK: The State Which Ran Away with Itself. How Is It Possible? Calvert 22, NSK Folk Art Catalogue, London. http://www.irwin.si/ texts/nsk-the-state-which-ran-away-with-itself/Last accessed 15. 08. 2017.

Pejić, Bojana. 2009. Proletarians of All Countries, Who Washes Your Socks? Equality, Difference and Dominance in Eastern European Art. In Gender Check. Femininity and Masculinity in the Art of Eastern Europe, ed. Bojana Pejić, 19-29. Cologne: Walther König.

Piotrowski, Piotr. 2012. Art and Democracy in Post-Communist Europe. London: Reaktion Books. 
194

Natalie Gravenor

List of Figures

Figure 1. Screenshot from Laibach's music clip Opus Lei (Life Is Life).

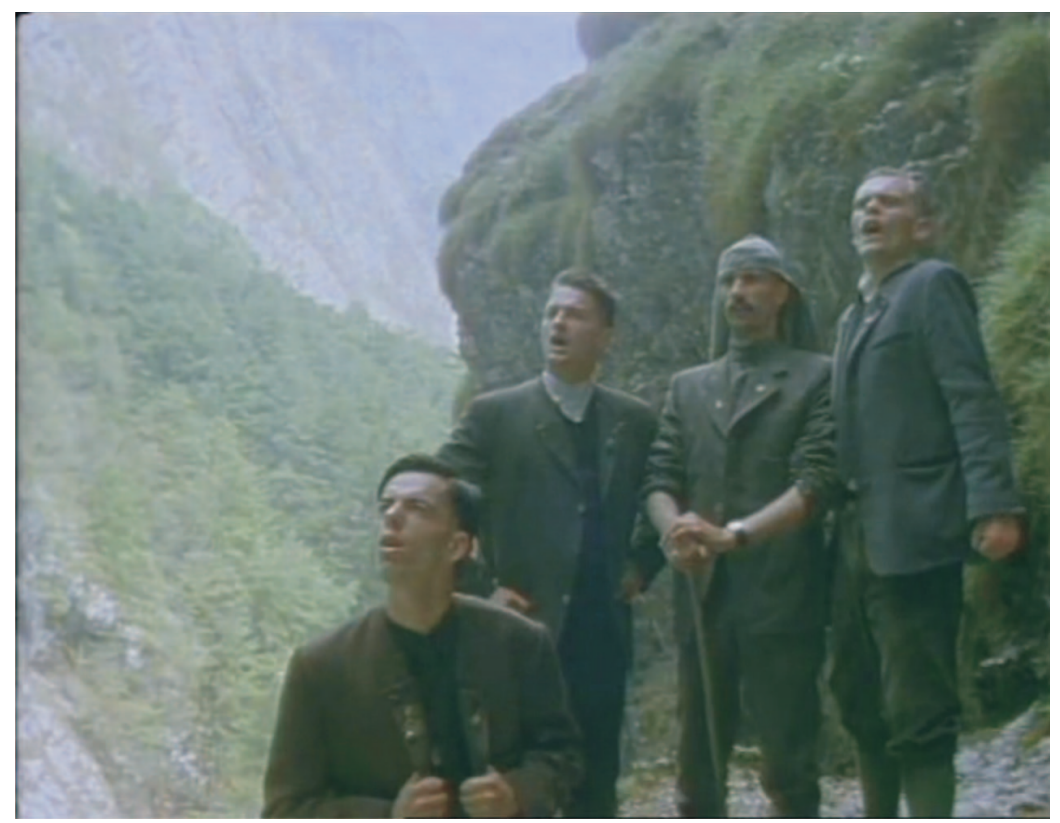

Figure 2. Screenshot of Država (The State).

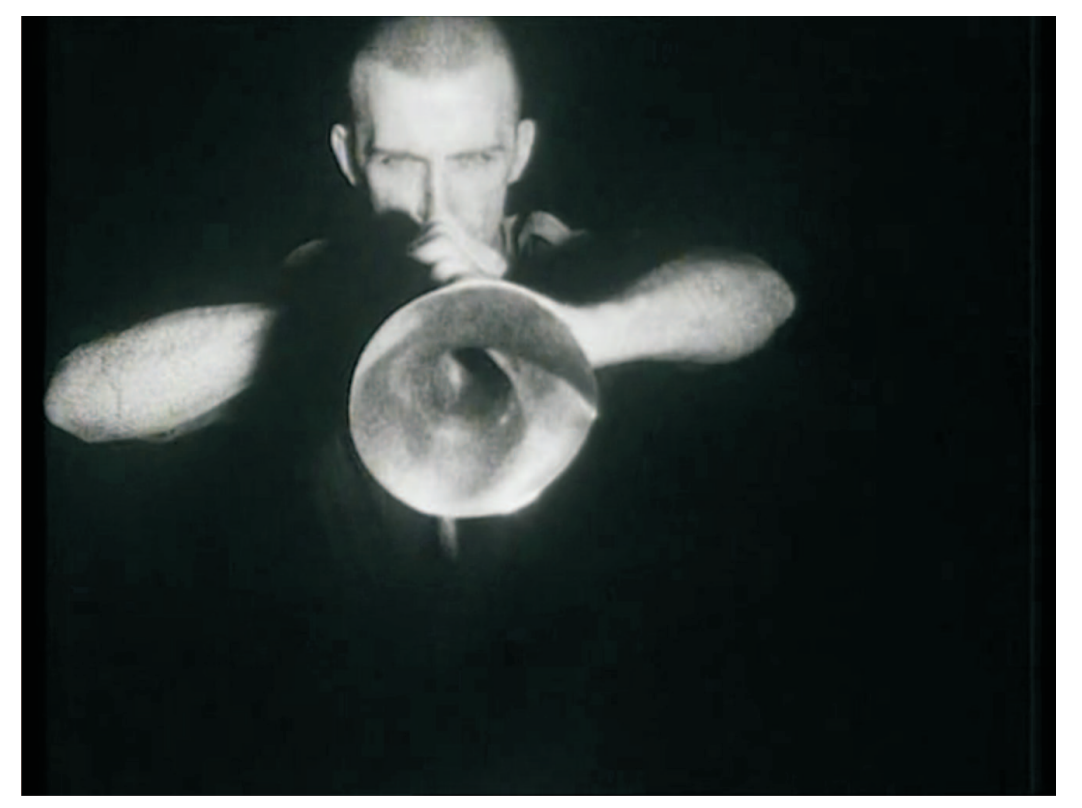


Figure 3. Screenshot of Wirtschaft ist tot (Economy is Dead).

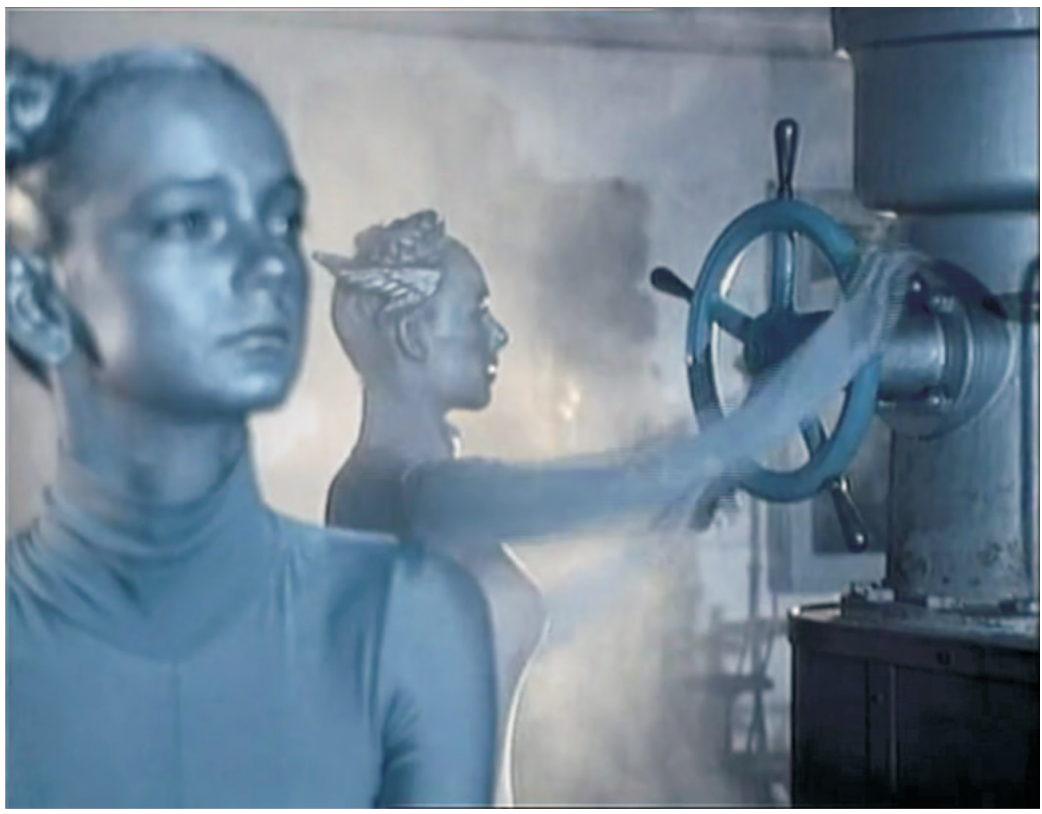

Figure 4. Screenshot of Final Countdown.

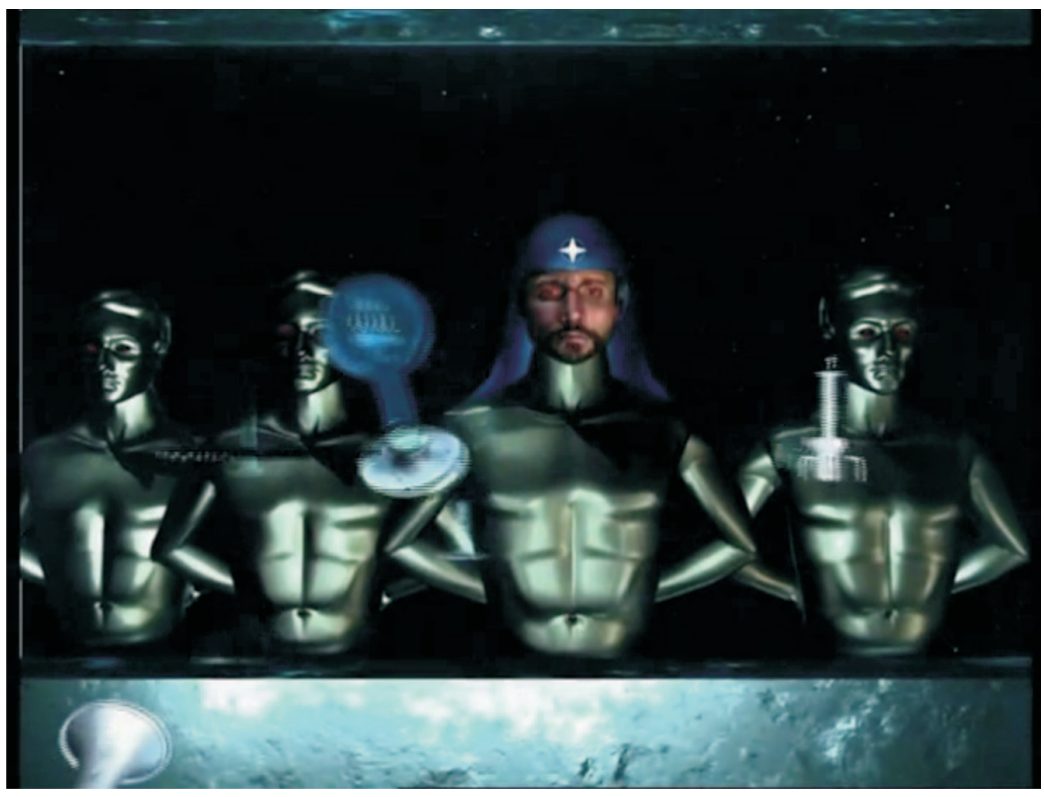


Figure 5. Screenshot of Miha Vipotnik's video documentation of Krst pod Triglavom (Baptism under the Triglav).

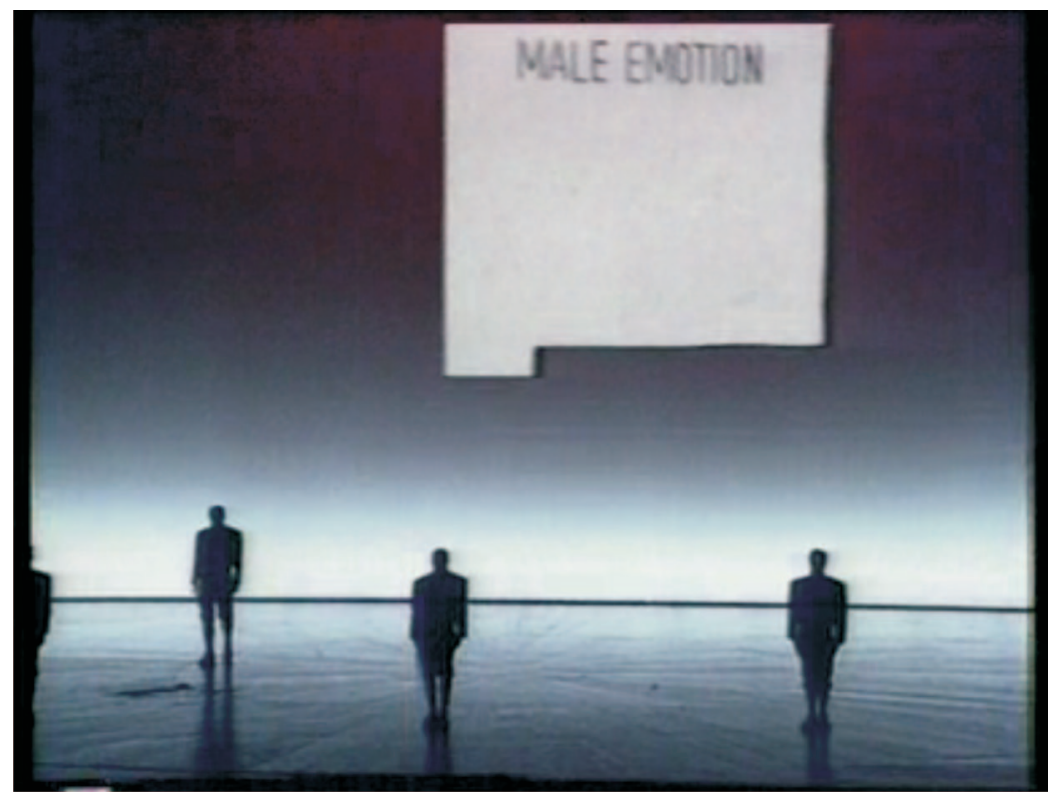

